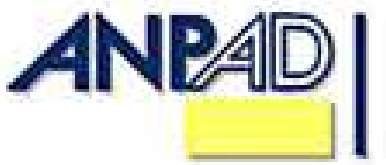

Available online at http://www.anpad.org.br/bar

BAR, Rio de Janeiro, v. 9, n. 3, art. 2, pp. 268-286, July/Sept. 2012

\title{
Perceptions of Equity and Justice and Their Implications on Affective Organizational Commitment: a Confirmatory Study in a Teaching and Research Institute
}

\author{
Moisés Balassiano * \\ E-mail address: moises@fucape.br \\ Fundação Instituto Capixaba de Pesquisas em Contabilidade, Economia e Administração - FUCAPE \\ Vitória, ES, Brazil. \\ Denise Salles \\ E-mail address: dsalles2003@yahoo.com.br \\ Universidade Federal Fluminense - UFF \\ Niterói, RJ, Brazil.
}

* Corresponding author: Moisés Balassiano

Fundação Instituto Capixaba de Pesquisas em Contabilidade, Economia e Administração - FUCAPE, Rua Fernando Ferrari, 1358, Boa Vista, Vitória, ES, 29075-505, Brazil.

Copyright (C) 2012 Brazilian Administration Review. All rights reserved, including rights for translation. Parts of this work may be quoted without prior knowledge on the condition that the source is identified. 


\begin{abstract}
Studies about individuals commitment to organizations acquire renewed interest in light of the changes imposed by new organizational structures and 'boundary-less' careers. The need to identify and retain individuals who add value to the organization constitutes an increasing challenge facing human resource professionals. In this context it is necessary to establish stronger links between the individuals and the organization they work for. In this paper the effects of the perceived equity and justice on the employees' affective commitment to the organization is evaluated, using a structural equation model. The main stream of the literature treats equity as part of distributive justice. The main contribution of this study was to treat both concepts separately. Based on data gathered from a teaching and research institute, this study confirmed the theoretical assumptions that the perception of justice is indeed antecedent to and determinant of affective organizational commitment. However, the same was not observed in relation to the perception of equity. This result justifies the new approach of removing the concept of equity from justice when measuring organizational commitment.
\end{abstract}

Key words: affective organizational commitment; perceived justice; perceived equity. 


\section{Introduction}

The complex aspects inherent to human relations have long been the subject matter of scholars and researchers in the social, human, and cultural domains. Significant implications for the agenda of human resource management have changed in work environments (Evans, Pucik, \& Tanure, 2007). The issue of deverticalization (unbundling) of organizational structures and the emergence of a new way for individuals to move forward in their professional lives is added to this phenomenon (Arthur \& Rousseau, 1996; Balassiano \& Costa, 2006). Questions concerning the centralization/decentralization of power, forms of cultural integration, attachment of individuals to organizations, among others, need to be considered in light of their impact on human resources, particularly those related to understanding how the affective facet of organizational commitment is generated and sustained. The central concepts of human resource management vary significantly among different cultures and cultural groups, with implications on the definition of their true role in the organization. Therefore, despite the influence of the internationalization process in labor relations nowadays, the values that establish a universally accepted model for human resource management are not yet clear.

Among the most striking features in organizational behavior are the perceptions of how organizations recognize employee's values and the way they show their appreciation (Brooke, Russel, \& Price, 1988; Morris \& Steers, 1980). Studies on the topic, conducted from both Business and Organizational Psychology perspectives, have shown that organizational affective commitment can be explained to a great extent by perceptions of justice (Kim \& Mauborgue, 1991, 1996, 1997; Mcfarlin \& Sweeney, 1992; Naumann, Bennett, Bies, \& Martin, 1998). Unfortunately such studies present mismatched, and sometimes inconclusive, results and do not enable comparisons or generalizations, given the bias of the area and/or different ways researchers operationalize this concept (Meyer \& Allen, 1991; Mowday, Steers, \& Porter, 1979).

This study aims to evaluate both the existence and significance of the relationship between perceptions of justice and equity on organizational commitment in its affective dimension based on a sample of employees from a teaching and research institute. It is expected that the results may contribute to the construction of systematic knowledge on the subject, as well as provide practitioners with the necessary tools to optimize the process of talent retention in organizations.

To this end, it was deemed appropriate to separate the two concepts - equity and justice, as antecedent elements of organizational commitment - and check their individual influence and impact on the affective commitment attitude of employees toward the organization. It was found that the justice perception factor can be considered as an antecedent to organizational commitment, confirming Rego (2002). However, the same was not true for the equity factor. This may lead to reflections on the value-based and relative nature of this concept, as well as the ambiguous consequences the perception of inequity can lead.

The theory of equity has been highlighted in the literature after the seminal work by Adams (1965), followed by others like Deutsch (1975), Leventhal (1980), and more recently by Bakhshi, Kumar, Rani (2009) and Burrus and Mattern (2010). According to those studies, the concept of equity is based on the perception of the way outcomes are consistent with the norm for allocation of rewards.

Studying issues related to affective organizational commitment in light of equity and justice perspectives requires methodologies that enable measurements and analyses appropriate to the context under analysis. Methodological issues have proven to be the main barriers to the convergence of results in investigations on the topic. Porter, Steers, and Mowday (2005), highlight the lack of any universal agreement on the definition of organizational commitment; demonstrating the different ways of defining this concept over the course of the past fifty years. Without a general consensus on what the concept actually represents, it becomes difficult to operationalize it; which may explain the divergences detected in the literature. 


\section{Human riddles}

The assumption that people are the key elements in organizational systems has occupied a central place in discussions on administrative issues ever since the Movement of Human Relations in the late 1920's. However, there is still little known about the human element and the forces present in its sphere of interaction.

According to Barnard (1971), no theory of organizations can exclude the knowledge of the intervening psychological forces in human behavior. In other words, human nature is the crux in understanding organizations. When such understanding does not happen, beliefs are taken for granted, leading to the implementation of the wrong administrative techniques. As a result, individual and organizational targets will not match, giving rise to ineffective or unreliable results.

Dejours (2002) and Goffman (2005) show the parallel existence of an administrative space and a human space in organizations. As a consequence, their rationales and subjectivities need to be integrated. However, the actual construction of the administrative space is nothing less than the result of individual actions, but instead of emerging from the individuals themselves, it evolves from systems of collective actions. The integration of those spaces causes changes in the individuals who need to behave under their functional rationale. As pointed by Barnard (1971), that adjustment provokes what, in some cases, is defined as the shaping of the individual to the organization personality; i.e., the aggregation and superimposition of institutional values upon personal values.

Making people efficient collaborators for the achievement of organizational effectiveness has always been the great challenge both in Administration theory - when developing techniques and procedures - and for managers when trying to apply them. However, beliefs and myths created and established around the motivational process obfuscate their understanding and lead to fragmented and misleading arguments in relation to complex human behavior. Thus, organizational vitality and longevity can be compromised, as they depend to a great extent on the willingness manifested by the actors to contribute to the achievement of institutional goals.

From the standpoint of organizational commitment, studies have been conducted since the 1970s in an attempt to operationalize the concept and identify its antecedents and its consequences (Mowday et al., 1979, p. 224). A gap that exists in the literature, however, refers to the lack of research and consensus on the possible influence of perceptions of justice and equity, respectively, on the affective commitment of individuals to their organizations. It is understood that this knowledge can influence managers in the definition of actions that lead employees to have such an attitude.

\section{Justice and Equity in Organizations: Complex Perceptions}

One of the starting points for the pursuit of knowledge about the perception of justice and equity by individuals and groups is attributed to the Theory of Inequity, proposed by Adams $(1963,1965)$. According to the author, in any trade-off relationship equity exists when the ratio between the investment and the return of an individual is perceived as being identical in terms of ratio to that of other people or groups, such that the recognition and relevance of inputs and investments are shared both by who is investing and who is the recipient of the investment. When this fails to occur, the relationship is considered inequitable; leading to tension between individuals who try to remedy the situation in a quest for the restoration of equity by means of cognitive adjustments. Furthermore, the perception of inequity affecting both the interpersonal and the organizational outcomes is not of logical, but instead, of emotional and psychological nature.

Rawls (1971) narrowed Adams' theoretical postulates seeking to identify what antecedents would lead individuals to perceive justice in the distribution of rewards. As a result, two conceptual criteria of justice were defined: distributive justice, which refers to the distribution of scarce goods; 
and the justice of criteria relating to the choice of procedures to be used in the distribution (Cropanzano \& Folger, 1991).

Adams (1965) also pointed out that the perception of equity in comparative judgment could lead to two types of emotions: anger - when people feel under-benefited, i.e., they do not receive enough when compared to others; and guilty - when they feel over-benefited, i.e., they receive too much when compared to others. Burrus and Mattern (2010) state that distributive justice judgments are formed by the concepts of equity, egoism, and egocentrism. They show that there is a tendency to judge, from a self-centered perspective, the relationship between their own contributions and those of others (based more heavily on assumptions); thus enabling new interpretations on the perception of equity.

Theoretical contributions that occurred after Adams, as reported by Paz (1999) and Mendonça (2003), sought to establish empirical evidence of his proposals and investigated the behavior of individuals in situations where they experienced feelings of injustice. However, this model of justice, as claimed by prevailing studies, proved to be limited, making it difficult to understand the psychological processes involved in this phenomenon (Santos \& Odelius, 2005). Thus, a systemic view of the issue brought to light other dimensions and further exacerbated the underlying theoretical questions.

The new directions of studies on organizational justice came to be based on the multidimensional approach characterized by the following dimensions:

1. Distributive justice: focus on content, on the justice of the ends achieved. This relates to wages, the results obtained in performance evaluations, promotions, awards, as well as disciplinary or administrative sanctions (Adams, 1965).

2. Procedural justice: focus on the process, on the means used to achieve the stated aims and distribute the rewards and sanctions. This relates to the procedures used in people management (Lind \& Tyler, 1988; Thibaut \& Walker, 1975).

3. Interactional justice: focus on interpersonal relations, on the treatment meted out by superiors to their subordinates, including that related to providing information and explanations about decisions that affect employees (Bies \& Moag, 1986; Greenberg, 1993; Rego \& Sousa, 2000; Tyler \& Bies, 1990).

According to Rego (2002), there are differences between the impacts of each of these dimensions on individual's behavior. If an individual perceives outcomes as being fair, the importance of procedures and interactions upon his reactions is reduced. In other words, unfair procedures or interactions are not capable of warranting retaliation and reduce his/her commitment. On the other hand, if the results are perceived as unfair, the individual tends to develop negative organizational attitudes and behaviors, such as dissatisfaction, poor performance, and absenteeism, among others. However, in this case, the existence of fair procedures and interactions may inhibit the individual from acting against the organization, despite the perception of injustice. The worst combination is that which brings together unfair results and unfair procedures and interactions (Santos \& Odelius, 2005). Whatever the case, it is considered that justice represents a non-dissociable part of human life; and because labor relations are part of life as a whole, it is also non-dissociable from organizational life and can influence individual and organizational group performance.

Cropanzano and Greenberg (1997) argue that eminently managerial decision-making processes include both aspects of procedural justice as well as interactional justice, as the two are related. According to Simons and Roberson (2003), the perception of interactional justice can be understood as an element of procedural justice, which refers to policies, practices and procedures of the organization, whereas interactional justice refers to the way in which these factors are transmitted by the managers to the employees. The Social Exchange Theory, based on Blau (1964), has been used to understand the distinction between procedural and interactional justice (Masterson, Lewis, Goldman, \& Taylor, 2000; Roch \& Shanock, 2006). 
The perception of justice is related to aspects of assessment and judgment exercised in the organizational environment, which are present in the interaction between the individual and his job. Bakhshi et al. (2009) found a significant correlation between organizational commitment and both procedural and distributive justice.

According to Dejours (2002), judgment of an individual job can work, on a subjective level, as recognition by other parties. This recognition refers to both the quality of the job and its contribution to management and organizational development. According to this approach, recognition can signify the moral-symbolic retribution given to individuals as a compensation for their contribution, through the engagement and commitment of their subjectivity and intelligence to the organization's effectiveness. Within the organization, the perception of justice implies the notion of judgment that lies in the recognition, and consequently on the prospects for individuals, in their sense of belonging and their identification with organizational values.

The perception of equity, in some aspects, is part of the perception of justice and, this being the case, can be analyzed from different perspectives. For the purposes of this study, the concept of equity was limited to its attitudinal aspect, i.e. the perception of equality of opportunities and possibilities offered by the organization. The ideas of symmetry and balance underlie the perception of equity, whereas the opposite exacerbates the perception of injustice, in the distributive, procedural and interactional dimensions.

Individuals' perceptions about equity, on the part of organizations, can be associated with positive outcomes of the relationship; such as organizational satisfaction and identification, and consequently commitment (Lee, 1971). On the other hand, perceptions of inequity, particularly those related to losses, can be associated with stress and dissatisfaction. This fact becomes more relevant when one considers equity as a phenomenon laden with subjectivity.

\section{Commitment in Organizations: a Multi-Faceted Concept}

According to Allen and Meyer (1990), Meyer and Allen (1991), Hackett, Byci, and Hausdorf (1994), Meyer (1997), and Iverson and Buttigieg (1999), organizational commitment is understood as a psychological state, as opposed to its attitudinal or behavioral nature (Salancik, 1977). In accordance with the new approach, taxonomy is defined based on three components: affective commitment (or desire); continuance commitment (or need), and normative commitment (or obligation). Table 1 summarizes their definitions. 
Table 1

The Three Components of Organizational Commitment

\begin{tabular}{llcc}
\hline Dimensions & \multicolumn{1}{c}{ Definition } & Motive for permanence & Psychological state \\
\hline Affective & $\begin{array}{l}\text { Extent to which employees feel emotionally } \\
\text { linked, identified and involved with the } \\
\text { organization. }\end{array}$ & Want to stay & Desire \\
Continuance & $\begin{array}{l}\text { Extent to which employees remain in the } \\
\text { organization due to the recognition of the } \\
\text { costs associated with quitting, the lack of an } \\
\text { alternative job, or the feeling that the } \\
\text { personal sacrifices generated by quitting } \\
\text { will be considerable high. }\end{array}$ & Need to stay & Need \\
Normative & $\begin{array}{l}\text { Extent to which employees have a moral } \\
\text { duty to remain in the organization }\end{array}$ & Must stay & Obligation \\
\hline
\end{tabular}

Note. Source: Allen, N. J., \& Meyer, J. P. (1990). The measurement and antecedents of affective continuance and normative commitment to the organization. Journal of Occupational Psychology, 63(1), 1-18. doi: 10.1111/j.20448325.1990.tb00506.x; Meyer, J. P., \& Allen, N. J. (1991). A three-component conceptualization of organization commitment. Human Resource Management Review, 1(1), 61-89. doi: 10.1016/1053-4822(91)90011-Z; Hackett, R. D., Bycio, P., \& Hausdorf, P. A. (1994). Further assessments of Meyer and Allen's (1991) three-component model of organizational commitment. Journal of Applied Psychology, 79(1), 15-23. doi: 10.1037/0021-9010.79.1.15; Meyer, J. P. (1997). Organizational commitment. In C. L. Cooper \& I. T. Robertson (Eds.), International review of industrial and organizational psychology (Vol. 2, pp. 175-228) and Iverson, R. D., \& Buttigieg, D. M. (1999). Affective, normative and continuance commitment: can the 'right kind' of commitment be managed? Journal of Management Studies, 36(3), 307-333. doi: $10.1111 / 1467-6486.00138$

Commitment, then, can be regarded as a multidimensional construct. However, the convergence, or association of such dimensions is not easily verified. Researchers, like Meyer and Allen (1991), Hackett et al. (1994), and Iverson and Buttigieg (1999), suggest the possibility that the ongoing continuance component has two dimensions: (a) individuals remain in their organizations because they feel like there is no alternative; and (b) the link is based on the idea that the personal costs inherent in quitting are too high. In the current environment with boundary-less careers, this component assumes capital importance due to the prevailing utilitarian relationship between individual and organization. On one hand, individuals remain in organizations until they envision some sort of perspectives (learning, career, etc.). On the other hand, companies retain the individuals as long as they add value and produce in accordance with expectations.

Despite its multidimensionality nature, organizational commitment is not invariant across companies (Rego, 2002). Individuals developing the affective commitment are more likely to show higher levels of job satisfaction, share organizational values more consistently, and have positive perceptions of justice, particularly in the interactional and/or procedural aspects. Cho, Bae, Ahn, and Lee (2009), by combining the transaction cost and the theory of social change approaches, identified judgments related to procedural and interactional justice. Such judgments, according to the authors, tend to play a central role in organizational outcomes in general, and organizational commitment, in particular.

According to Allen and Meyer (1996), Meyer (1997), and Iverson and Buttigieg (1999), employees with affective commitment are less likely to quit their job and present lower level of absenteeism, when contrasted, for example, to those with continuance commitment. Also, affective commitment is more related to higher performance. In other words, there is evidence that the desire of individuals to contribute to organizational goals is influenced by the nature of the psychological ties that bind them to the organization. According to Rego (2002), it is more likely that individuals undertake major efforts to perform well when they want to stay in the organization than when they feel obliged to remain there. However, Porter et al. (2005) conclude that some of the possible consequences of organizational commitment, in practice, do not assume the dimensions proclaimed in 
the literature. Indeed, they show a weak correlation with the performance of individuals and a moderate correlation with absenteeism, albeit a high negative correlation with the turnover of the workforce. The authors consider that the intrinsic nature of the commitment is comprised of more profound and intense elements than those forming attitudes of loyalty to organizations. They present a definition of organizational commitment as "the relative strength of an individual's identification with a particular organization" (Porter, Steers, \& Mowday, 2005, pp. 181-184). In essence, this definition emphasizes the active relationship between workers and the organization, such that the former will always be prone to give something of themselves to improve the organizational welfare.

According to Bastos, Brandão and Pinho (1997), organizational commitment is related to the effort and care that individuals put into carrying out a given activity. Thus, the commitment also comes to mean a state of the individual, which may refer to a state of loyalty to something that can be described by intentions, feelings, and desires. However, this state can be defined along a continuum with extremes describing opposing value dimensions: (a) commitment as a form of behavior leading to desirable states at the positive extreme; and (b) commitment as a form of involvement that may hamper people's actions at the negative extreme. Commitment is considered, therefore, as a state characterized by affective feelings or reactions, such as loyalty towards something to which specific behavioral intentions are associated, as supported by Bakhshi et al. (2009). Within the scope of studies on the relationship between individuals and the organization, commitment is mainly treated from the attitudinal standpoint.

When used in corporate jargon, the concept comes to have reduced amplitude, meaning only engagement and adherence, eliminating the content with a negative connotation. Thus, the most common meanings are: (a) desire to remain, continue, a sense of pride in belonging; (b) identification, attachment, involvement with goals and values; and (c) engagement, effort, commitment. As mentioned, there is a presumption that those most committed are more likely to extend their stay in the organization and to excel in the conduct of their activities in line with organizational goals (Allen \& Meyer, 1996; Meyer, 1997; Meyer \& Allen, 1997).

The organizational commitment can be understood, for the purpose of this work, as the psychological links that are forged between individuals and the organization. The underlying belief is that the individuals' commitment induces positive effects on the effectiveness of the organizations where they work, even making them able to withstand highly demanding working conditions (Rego, 2002). This fact has its origin in the individual's emotional ties with the organization, represented by loyalty, attachment, and trust.

It should be noted that the very concept of organizations is problematic by definition; in that they are not single, undifferentiated entities, which elicit commitment in general terms and identification on the part of the individual. Organizations are in fact comprised of multiple segments (Bastos, Brandão, \& Pinho, 1997) that do not always share the same goals and values. For example, management, worker groups, shareholders, among others, may have differentiated objectives, regardless of the explicit mission of the organization. This assumption has clear implications for the study of organizational commitment, as also occurs for concepts of organizational climate, which should go beyond a global measure and be broken down into specific commitments.

Borges-Andrade and Pilati (2001) highlight some factors that could cause changes in the standards of individual's involvement. They include: (a) self-management of careers which, by exacerbating individualism and commitment of people to their own interests, does so at the expense of a decrease in organizational commitment; (b) large-scale outsourcing and staff reductions can be interpreted as signs of a violation of the psychological contract between the organization and the employee, which could lead to a lower levels of commitment; (c) the labor organization increasingly concentrated around autonomous teams can increase commitment to the team and decrease commitment to the organization as a whole. In addition, we observe movements towards workforce reduction imposed by programs such as re-engineering, downsizing, and voluntary early retirement, which greatly affect the relationship between individuals and organizations, creating an environment surrounded by uncertainty and suspicion. 
To redeem the trust between organizations and individuals, it is necessary to establish a code based on the uncertainty avoidance. Hypothetical elements in the predisposition to such values arise in principle from sentiments of justice and equity as a way of retaining the resources needed to optimize organizational results. The effective contribution of this work is the evaluation of these hypotheses.

\section{Methodological Aspects}

In line with the overriding objective of this work, a confirmatory study was designed to enable assessment of the significance of relations involving the psychological states of organizational equity and justice with organizational commitment. The methodological principles that were used to implement the study are presented below.

\section{Sample}

A non-probabilistic sample of 73 employees with high school and college degrees, working as technical and administrative support in a teaching and research institution was selected. Attempts were made to diversify the sample in terms of its composition, in order to have the same demographic profile found in the population at the institution as a whole. The selected employees work in the two main sectors of the institution, namely teaching and research. The purpose of the diversity was to capture potential intra-institutional differences regarding the respondents' perceptions.

Over the last thirty years or so much attention has been given to sample size in Structural Equation Modeling literature. Hair, Anderson, Tatham, and Black (1998, p. 604) describes four factors influencing the choice of an adequate sample size. One of them is the minimum sample required when Maximum Likelihood method of parameter estimation is used. In this case the author states that samples of 50 units have provided valid results, although should not be recommended. Tanaka (1987), using the Monte Carlo approach to the problem suggests that for latent variable models the sample size should be based on the subject to parameter estimates ratio. Ad hoc rules of thumb, however, place the size of the sample on the subject to item ratio. Costello and Osborne (2005) summarize over 1700 studies using Exploratory Factor Analysis from PsychINFO concluding that subject to item ratio ranged from 2:1 to more than 100:1, with modal choice between 5:1 and 10:1. Future studies should assess the role of the sample plan, rather than the sample size, to ensure adequate statistical power to parameter estimates; i.e., the choice of random, stratified, clustered, single/multiple stages samples, to cite the more important ones. The sample plan, based on the population features, leads to the adequate sample size, not the other way round (Cochran, 1977, p. 7).

In the present study we employed the Maximum Likelihood method to estimate the model parameters. The overall and individual measures of the model fit did not show evidence of any kind of model or parameter illness, and the measure of the adequate sampling was 0.869 ; therefore the sample can be accepted as adequate for the analyses.

\section{Data}

A questionnaire consisting of three non-apparent sessions was submitted, with items developed on the basis of the bibliographical review and in accordance with the conceptual typology expressed in the theoretical reference section of this study. Items related to Equity tried to capture the respondent's perception about the opportunities provided by the institution, giving the sense of the balance between inputs and outcomes when compared with others. Justice items captured the fairness in the way the institution distributes the outcomes (distributive justice facet) and the process used to do so (procedural justice facet). At last, items measuring affective commitment were based on the affective items of the Organizational Commitment Questionnaire (OCQ) by Mowday, Steers, and Porter (1979). 
Because of the specificity of this study no existing validated scale could be used. The items were presented as assertions in line with a four-point Likert scale.

There has always been a tradeoff regarding the choice of the number of categories to be considered when working with categorical variables. On one hand, the larger the number of categories of a qualitative variable, the closer it becomes to a scaling variable, allowing for quantitative statistical measures; but the price to be paid is that respondents may not be able to discriminate accordingly between closer options, like satisfied, somehow satisfied and little satisfied, adding bias to the scale. On the other hand, the smaller the number of categories, the poorer the scale, but less bias will be added to the scale. Motta (1999, p. 55) suggests 5 categories as a balance between good discrimination and less bias. The four point scale was an option to avoid neutral responses, forcing the respondents to make a better positive or negative judgment about the concept being measured. Table 2 below presents the assertions as submitted.

Table 2

Items Submitted for Operationalization of the Concepts

\begin{tabular}{cl}
\hline Variable & \multicolumn{1}{c}{ ITEMS } \\
XE1 & In the organization I work all employees have opportunities to display their talents. \\
XE2 & $\begin{array}{l}\text { The organization I work for offers the possibility for engaging in challenging work and } \\
\text { professional development, regardless of the position held. }\end{array}$ \\
XE3 & $\begin{array}{l}\text { The organization I work for has qualification and training policies for all employees, } \\
\text { regardless of the positions held. }\end{array}$ \\
XEJ4 & $\begin{array}{l}\text { The Human Resources policies in the organization where I work promote affirmative } \\
\text { action for all employees, regardless of the position held. }\end{array}$ \\
XJ5 & $\begin{array}{l}\text { The organization I work for has compensation policies that benefit employees with good } \\
\text { performance. }\end{array}$ \\
XJ6 & $\begin{array}{l}\text { The assessment of my job performance is conducted in a fair way, with known and } \\
\text { transparent criterion. }\end{array}$ \\
XJ7 & My dedication and effort to the organization are recognized and appreciated. \\
XJ8 & The salary and benefits I receive are compatible with my dedication. \\
XJ9 & The criteria for promotion in the organization I work for are fair. \\
Y10 & I intend to develop my entire professional career in this organization. \\
Y11 & I belong to an organization that has an important mission for society. \\
Y12 & My work is important for the efficiency of the organization. \\
Y13 & I feel proud and am professionally fulfilled by working in this organization. \\
\hline
\end{tabular}

\section{Constructs, indicators and hypotheses}

Despite the confirmatory nature of the study, where each indicator is previously defined and supposedly measures a specific construct, a test was performed consisting of an exploratory factor solution based on the correlation matrix between the indicators to assess the extent to which the theoretical assumptions of the indicators were being consistently defined. This procedure is largely used to assess the construct validation of a measure (Colquitt, 2001), and follows, partially, the proposition of Cabrera-Nguyen (2010) to report scale development and validation. The procedure led to the reassessment of the initial model as one of the indicators, XEJ4, showed signs of simultaneously measuring the two exogenous constructs, namely Equity and Justice. This is a case that the literature identifies as a "complex indicator" (McDonald, 2000, p. 102). According to the structure observed in 
Table 3, the items fitted the 3 factor solution, and discriminated nicely between the concepts of equity and justice.

The test of sphericity of the association matrix in the population rejected the null hypothesis of independence between the variables, with significance less than $0.1 \%$, indicating the adequacy of the analytical technique. The three dimensions explained $67 \%$ of the total variations in the variables.

Table 3 presents the simple structure of the dimensions represented by the rotated load pattern. To avoid a general factor, the varimax (orthogonal) rotation method was performed after a normalization process, i.e. dividing the unrotated loadings by the square root of the respective communality, to make each row sum of squares unity (Kaiser, 1958). Recall that varimax rotation technique forces each variable to load highly in few dimensions and lower in the remaining ones, to provide a clearer interpretation of the dimensions. For a better understanding of the adjustment of the indicators to their respective dimensions, loadings below 0.5 have been omitted. Cronbach's alpha coefficient for each scale has also been provided in Table 3. All coefficients are in the range of what can be regarded as consistent scales (Cronbach, 1951).

Table 3

Load Factors after Varimax Rotation

\begin{tabular}{cccc}
\hline & & \multicolumn{3}{c}{ Constructs } \\
\cline { 2 - 4 } Variables & Justice & Equity & Commitment \\
\hline Y10 & & & .648 \\
Y11 & & .707 \\
Y12 & & .798 \\
Y13 & & .674 \\
XE1 & & .850 & \\
XE2 & & .866 & \\
XE3 & & .695 & \\
XEJ4 & .579 & .615 & \\
XJ5 & .631 & & \\
XJ6 & .764 & & \\
XJ7 & .779 & & \\
XJ8 & .719 & & \\
XJ9 & .773 & & \\
Alpha & $\mathbf{0 . 8 9}$ & $\mathbf{0 . 8 7}$ & \\
\hline
\end{tabular}

Note. Extraction Method: Principal Component Analysis. Rotation Method: Varimax with Kaiser Normalization.

A structural equations model was built involving the concepts of Equity and Justice, as perceived by employees, hypothetically affecting the predisposition of Organizational Commitment. The hypotheses established by the model are:

$\mathbf{H}_{\mathbf{0 1}}$ : The perception of equity affects the affective organizational commitment.

$\mathbf{H}_{\mathbf{0} 2}$ : The perception of justice affects the affective organizational commitment.

Having identified the model parameters, evaluated the load factors, and validated the scale of the constructs, a test was then conducted to verify the hypotheses: how each of the exogenous factors (Equity and Justice) possibly influences the endogenous factor (Commitment). 


\section{Data analysis}

To run the model, the polychorical correlations between the manifest variables were calculated to measure their pairwise degree of association (Muthén, 1978). According to Jöreskog and Sörbom (1996), this is the measure of association suitable for variables with ordinal level of measurement. The version 8.33 of LISREL program was then used to estimate the loadings associated with the relations established. All coefficients of the measurement sub-model for the two exogenous latent variables (Equity and Justice) and the endogenous latent variable (commitment) were significant at 5\%.

Table 4 presents a summary of the coefficients, the respective t-values and the standardized coefficients for the latent exogenous factors. To fix the scale of the latent factors, as well as to guarantee the identifiability of the model, a unitary value was assigned for the relationship between one of the variable indicators and the respective concept measured by them.

In accordance with the results, all the indicators loaded the respective factors significantly at the $5 \%$ level. The standardized coefficients were calculated to enable a comparative evaluation among indicators with higher impact for each factor. It was noted that Engaging in challenging work and Opportunity to display their talents loaded highly on Equity perception, whereas Affirmative action of HR policies had the lowest load. As for the sense of Justice, Recognition of effort and dedication was the most significant, whereas Compensation compatible with dedication had the lowest load.

Table 4

Load Factors, t-Statistics and Standardized Load of the Latent Exogenous Variables

\begin{tabular}{llccc}
\hline \multirow{2}{*}{ Factors } & \multicolumn{1}{c}{ Indicators } & $\begin{array}{c}\text { Load } \\
\text { Factor }\end{array}$ & t-value & $\begin{array}{c}\text { Standard } \\
\text { load }\end{array}$ \\
\hline Equity & Opportunity & 1.00 & -- & 0.87 \\
& Engagement & 1.01 & 9.06 & 0.88 \\
& Training & 0.85 & 7.12 & 0.73 \\
& Affirmative action & 0.34 & 2.35 & 0.30 \\
\hline Justice & Affirmative action & 0.77 & 4.36 & 0.59 \\
& Compensation policy & 1.00 & -- & 0.78 \\
& Recognition and effort & 1.06 & 7.40 & 0.82 \\
& Evaluation & 0.94 & 6.42 & 0.73 \\
& Comparative compensation & 0.68 & 4.44 & 0.53 \\
& Promotion criteria & 1.03 & 7.18 & 0.80 \\
\hline
\end{tabular}

For the Commitment factor all indicators loaded significantly at 5\% level in the two factors. Proud to belong to the institution was the feeling with the highest impact on Commitment with a standard load of 0.91, whereas Recognizing the importance of the mission of the institution on the national scene was the indicator with the least impact. 
Table 5

Load Factor, t-Statistics of the Latent Exogenous Variables

\begin{tabular}{llccc}
\hline LATENT FACTOR & \multicolumn{1}{c}{ Indicators } & Load Factor & t-value & Standard Load \\
\hline COMMITMENT & Intention to make a career & 1.00 & -- & 0.63 \\
& Importance in the national scenario & 0.70 & 3.28 & 0.44 \\
& Importance of the task performed & 0.75 & 3.53 & 0.48 \\
& Proud to belong to the organization & 1.44 & 4.91 & 0.91 \\
\hline
\end{tabular}

The significance of the structural model's coefficients makes it possible to test the hypotheses about the effective causes of organizational commitment, when evaluated by the perceptions of Equity and Justice. The estimated coefficients for the structural relationships as defined by the model are presented below, in Table 6 .

Table 6

Estimated Coefficients and t- and p-Values for the Structural Relationships

\begin{tabular}{cccccc}
\hline \multirow{2}{*}{$\begin{array}{c}\text { EXPLAINED } \\
\text { FACTOR }\end{array}$} & EXPLANATORY & \multicolumn{2}{c}{ COEFFICIENTS } & \multicolumn{2}{c}{ VALUE } \\
\cline { 3 - 4 } & FACTORS & ABSOLUTE & STANDARD & t- & p- \\
\hline COMMITMENT & EQUITY & 0.08 & 0.11 & 0.61 & 0.54 \\
& JUSTICE & 0.43 & 0.54 & 2.51 & 0.01 \\
\hline
\end{tabular}

The perception of Equity was not significant for explaining institutional Commitment at 5\%. Only the perception of Justice is related to Commitment at 5\% significant level. The correlations between Commitment and its hypothetical explanatory factors were 0.49 for Equity and 0.61 for Justice. The two explanatory factors revealed a high correlation of 0.73 .

In essence, according to the results obtained from the structural model, we can conclude that only hypothesis 2 can be confirmed. In other words, whereas Justice perception affects institutional commitment, Equity perception did not reveal any effect. Figure 1 summarizes the proposed model, presenting its coefficients.

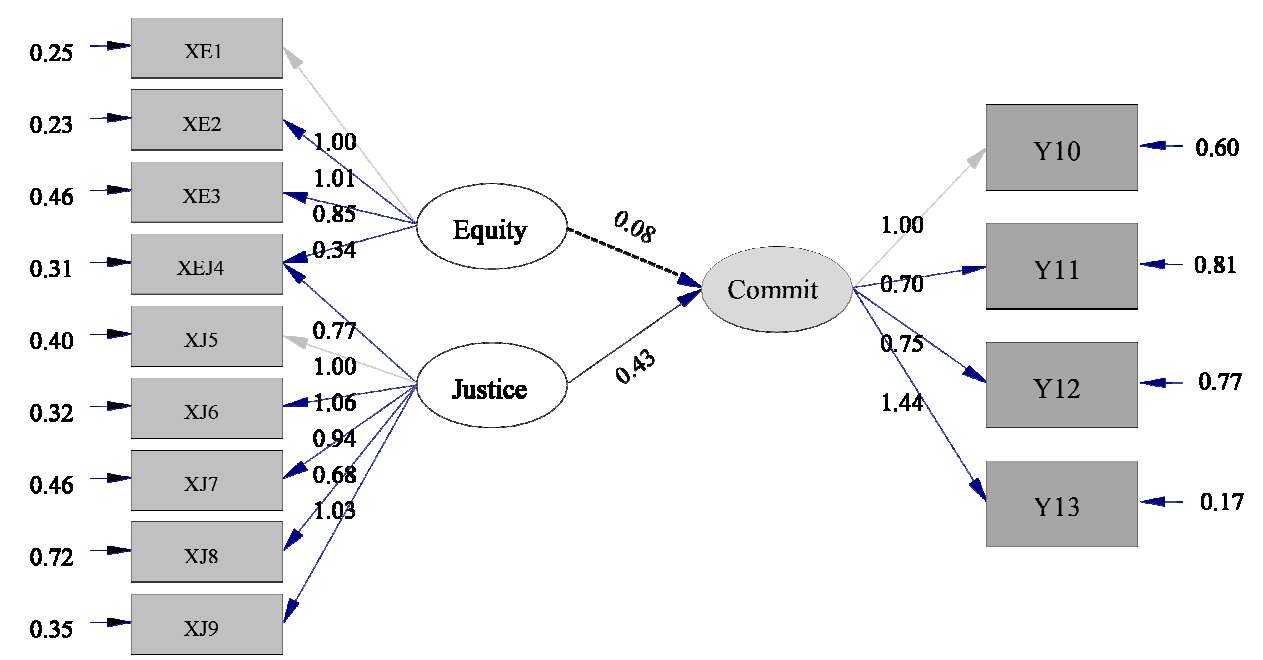

Chi - Square $=60.07, \mathrm{df}=61, \mathrm{P}-$ value $=0.50960, \mathrm{RMSEA}<0.001$

Figure 1. Structural Equation Model with the Coefficients. 
The proposed model proved to be adjusted, with the chi-square value equals to 60.07 with 61 degrees of freedom, with a significance of 0.5096, which leads to a non-rejection of the model. As an overall measure of model fit, the Root Mean Square Error of Approximation (RMSEA) less than 0.0001 indicates an excellent adjustment of the data to the model (MacCallum, Browne, \& Sugawara, 1996).

\section{Conclusions}

One of the major challenges of Human Resources management is to understand the factors that lead individuals to become committed to their organizations. Researchers have developed models of global and specific measures of commitment considering the concept of organizational justice as an antecedent factor (Meyer \& Allen, 1991; Mowday et al., 1979; Porter et al., 2005). In the literature, the concept of Equity is usually presented as a construct inherent to that of Distributive Justice.

In this research, Equity was treated as a construct with its own representation, trying to capture how the opportunities are presented to individuals in the organization. Although, as expected, Equity was highly correlated with Justice, both concepts were proposed as antecedents to commitment in their own right. The effects of this separation constitute the main theoretical contribution of this study. However, as shown by the results of the model, the hypothesis is that Equity, as perceived by the employees, has no effect on organizational commitment. Future studies may attempt to conduct an indepth evaluation of this concept in some alternative manner, leading to a different operationalization in order to better assess the effectiveness of the separation of the two constructs.

The results also lead to reflections on the possible influences of individual and collective approaches in individual's perceptions. The set of equity indicators, as defined in the present study, related to the collective more than to the individual aspects, whereas justice indicators blended individual and collective approaches. Because the study has showed that Justice influences organizational commitment, while the perception of equity doesn't, the role of individual and collective approaches in the perception of organizational justice may be the subject of subsequent studies.

The prevalence of the affective aspect of commitment in the study - represented by the higher load factor for the proud to belong institutional indicator, and the influence of the recognition indicator relating to the justice construct - should also be emphasized. They confirm the power of the subjective aspects inherent in the topics analyzed. This fact is relevant for the development of policies in the Human Resources management field as well as for the development of research on the influence of affectivity on organizational performance.

Attitudinal commitment, more bound to affective aspects, seems to be an outcome from the trade-off relationship that bridges the individual and the organization. There seems to be a clear separation between the affective perceptions of individuals in relation to the organization and their perceptions regarding actions in the workplace. As one is dealing with a trade-off relationship involving feelings and emotions, a gradual social construction would seem to occur, leading to a strengthening of the relationship between individuals and the organization. Thus, commitment based on attitudes and emotions cannot be transformed by the organizations in the short term, though it might be an outcome of a careful medium and long term relationship construction.

Although much has been accomplished and developed on the theme, a series of future studies will certainly bring greater theoretical clarity and the possibility of applications on the determinants and consequences of organizational commitment. Among them, to name the most important and immediate, are: (a) an evaluation of the real consequences of commitment in light of an unstable labor market with utilitarian relationships; (b) exploration of the sources of perceptions of organizational justice and equity seeking to enhance the scope of the operationalization of these concepts; (c) 
identification of the various nuances of the concepts of justice, equity and commitment, in accordance with different cultural contexts; and (d) identification of instruments and actions that lead to positive perceptions of justice and equity on the part of individuals.

In the final analysis, the research conducted into organizational commitment has provided information for the formulation and development of organizational policies that seek to strengthen the ties that bind workers to their work and their organization, in line with the psychological contract established. As a result, there is still a long way to go, with multiple perspectives for in-depth theoretical study in the area.

Among the limitations this study might have, the possibility that correlations between variables were affected by common method variance bias is present. Although items had been randomly presented to respondents, self-report measures are always a potential source of spuriously inflated correlation between variables, leading to biased constructs. The reduced number of items operationalizing a construct may also threat its content validity. Future studies should try to extend the domain of the concepts herein presented. Finally, the results obtained in this study may be context sensitive, in the sense that the relationships found in this study may not be true in contexts different from the academic environment used as the scenario for the present study.

\section{Received 14 December 2010; received in revised form 26 October 2011.}

\section{References}

Adams, J. S. (1963). Towards an understanding of inequity. Journal of Abnormal and Social Psychology, 67(5), 422-436. doi: 10.1037/h0040968

Adams, J. S. (1965). Inequity in social exchange. In L. Berkowitz (Eds.), Advances in experimental social psychology (Vol. 2, pp. 267-299). New York: Academic Press.

Allen, N. J., \& Meyer, J. P. (1990). The measurement and antecedents of affective continuance and normative commitment to the organization. Journal of Occupational Psychology, 63(1), 1-18. doi: $10.1111 / \mathrm{j} .2044-8325.1990 . t b 00506 . x$

Allen, N. J., \& Meyer, J. P. (1996). Affective, continuance and normative commitment to the organization: an examination of interactive effects of outcomes and procedures. Psychological Bulletin, 2(120), 189-208.

Arthur, M. B., \& Rousseau, D. M. (1996). The boundaryless career as a new employment principle. In M. B. Arthur, \& D. M. Rousseau (Eds.), The boundaryless career: a new employment principle for a new organizational era (pp. 3-20). New York: Oxford University Press.

Bakhshi, A., Kumar, K., \& Rani, E. (2009). Organizational justice perceptions as predictor of job satisfaction and organizational commitment. International Journal of Business and Management, 4(9), 145-154.

Balassiano, M., \& Costa, I. S. A. (2006). Gestão de carreiras: dilemas e perspectivas. São Paulo: Atlas.

Barnard, C. (1971). As funções do executivo. São Paulo: Atlas.

Bastos, A. V. B., Brandão, M. G. A., \& Pinho, A. P. M. (1997). Comprometimento organizacional: uma análise do conceito expresso por servidores universitários no cotidiano de trabalho. Revista de Administração Contemporânea, 1(2), 97-120. doi: 10.1590/S1415-65551997000200006 
Bies, R. J., \& Moag, J. S. (1986). Interactional justice: communication criteria of equity. In R. J. Lewicki, B. H. Sjeppard, \& M. H. Bazerman (Eds.), Research on negotiation in organizations (pp. 43-55). Greenwich, CT: JAI Press, v.1.

Blau, P. M. (1964). Exchange \& power in social life. New York: John Wiley \& Sons, Inc.

Borges-Andrade, J. E., \& Pilati, R. (2001). Comprometimento atitudinal e comportamental: relações com suporte e imagem nas organizações. Revista de Administração Contemporânea, 5(3), 85106. doi: 10.1590/S1415-65552001000300005

Brooke, P. P., Russell, D. W., \& Price, J. L. (1988). Discriminant validity on measures of job satisfaction, job involvement, and organizational commitment. Journal of Applied Psychology, 73(2), 139-145.

Burrus, J., \& Matern, K. D. (2010). Equity, egoism, and egocentrism: the formation of distributive justice judgments. Basic and Applied Social Psychology, 32(2), pp. 155-164. doi: $10.1080 / 01973531003738593$

Cabrera-Nguyen, P. (2010). Author guidelines for reporting scale development and validation results in the journal of the society for social work and research. Journal of the Society for Social Work and Research, 1(2), 99-103. doi: 10.5243/jsswr.2010.8

Cho, S., Bae, J., Ahn, S., \& Lee, K. (2009, January). The relationship between organizational justice and organizational outcomes by combining transaction cost approach with social exchange theory. Proceedings of the Southern Political Science Association Annual Meeting, New Orleans, LA.

Cochran, D. G. (1977). Sampling techniques. New York: John Wiley \& Sons Inc.

Colquitt, J. A. (2001). On the dimensionality of organizational justice: a construct validation of a measure. Journal of Applied Psychology, 86(3), 386-400.

Costello, A. B., \& Osborne, J. W. (2005). Best practices in exploratory factor analysis: four recommendations for getting the most from your analyses. Practical Assessment, Research \& Evaluation, 10(7), 1-9.

Cronbach, L. J. (1951). Coefficient alpha and the internal structure of test. Phychometrika, 16(3), 297334. doi: 10.1007/BF02310555

Cropanzano, R., \& Folger, R. (1991). Procedural justice and worker motivation. In R. M. Steers \& L. W. Porter (Eds.), Motivation and work behavior (5th, pp. 131-143). New York: McGraw Hill, Inc.

Cropanzano, R., \& Grennberg, J. (1997). Progress in organizational justice: tunneling through the maze. In C. L. Cooper \& I. T. Robertson (Eds.), International review of industrial and organizational psychology (Vol. 2, pp. 317-372). New York: Wiley.

Dejours, C. (2002). O fator humano. Rio de Janeiro: FGV.

Deutsch, M. (1975). Equity, equality and need: What determines which value will be used as the basis of distributive justice? Journal of Social Issues, 31(3), 137-149. doi: 10.1111/j.15404560.1975.tb01000.x

Evans, P., Pucik, V., \& Tanure, B. (2007). A gestão de pessoas no Brasil: virtudes e pecados capitais. Rio de Janeiro: Campus/Elsevier.

Goffman, E. (2005). A representação do eu na vida cotidiana (13th ed.). Petrópolis: Vozes. 
Greenberg, J. (1993). The social side of equity: interpersonal and informational classes of organizational justice. In R. Cropanzano (Ed.), Justice in workplace: approaching equity in human resource management (pp. 79-103). Hillsdale, NJ: Erlbaum.

Hackett, R. D., Bycio, P., \& Hausdorf, P. A. (1994). Further assessments of Meyer and Allen's (1991) three-component model of organizational commitment. Journal of Applied Psychology, 79(1), 15-23. doi: 10.1037/0021-9010.79.1.15

Hair, J. F., Jr., Anderson, R. E., Tatham, R. L., \& Black, W. C. (1988). Multivariate data analysis (5th ed.). Upper Saddle River, NJ: Prentice Hall.

Iverson, R. D., \& Buttigieg, D. M. (1999). Affective, normative and continuance commitment: can the 'right kind' of commitment be managed? Journal of Management Studies, 36(3), 307-333. doi: $10.1111 / 1467-6486.00138$

Jöreskog, K. G., \& Sörbom, D. (1996). LISREL 8: user's reference guide. Chicago, IL: Scientific Software International.

Kaiser, H. F. (1958). The varimax criterion for analytic rotation in factor analysis. Psychometrika, 23(3), 187-200. doi: 10.1007/BF02289233

Kim, W. C., \& Mauborgne, R. A. (1991). Implementing global strategies: the role of procedural justice. Strategic Management Journal, 12(S1), 125-143. doi: 10.1002/smj.4250120910

Kim, W. C., \& Mauborgne, R. A. (1996). Procedural justice and managers' in-role and extra-role behavior: the case of the multinational. Management Science, 42(4), 499-515. doi: $10.1287 / \mathrm{mnsc} .42 .4 .499$

Kim, W. C., \& Mauborgne, R. A. (1997). Fair process: managing in the knowledge economy. Harvard Business Review, 75(4), 65-75.

Lee, S. M. (1971). An empirical analysis of organizational identification. Academy of Management Journal, 14(2), 213-226.

Leventhal, G. S. (1980). What should be done with equity theory? New approaches to the study of fairness in social relationships. In K. Gergen, M. Greenberg, \& R. Willis (Eds.), Social exchange: advances in theory and research (pp. 167-218). New York: Springer-Verlag.

Lind, E. A., \& Tyler, T. R. (1988). The social psychology of procedural justice (critical issues in social justice). New York: Springer-Verlag.

MacCallum, R. C., Browne, M. W., \& Sugawara, H. M. (1996). Power analysis and determination of sample size for covariance structure modeling. Psychological Methods, 1(2), 130-149.

Masterson, S. S., Lewis, K., Goldman, B. M., \& Taylor, M. S. (2000). Integrating justice and social exchange: the differing effects of fair procedures and treatment on work relationship. The Academy of Management Journal, 43(4), 738-748.

McDonald, R. P. (2000). A basis for multidimensional item response theory. Applied Psychological Measurement, 24(2), 99-114.

McFarlin, D. B., \& Sweeney, P. D. (1992). Distributive and procedural justice as predictors of satisfaction with personal and organizational outcomes. Academy of Management Journal, 35(3), 626-637. doi: 10.2307/256489

Mendonça, H. (2003). Retaliação organizacional: o impacto dos valores e da justiça (Doctoral thesis). Instituto de Psicologia, Universidade de Brasília, Brasília, Brazil. 
Meyer, J. P. (1997). Organizational commitment. In C. L. Cooper \& I. T. Robertson (Eds.), International review of industrial and organizational psychology (Vol. 2, pp. 175-228).

Meyer, J. P., \& Allen, N. J. (1991). A three-component conceptualization of organization commitment. Human Resource Management Review, 1(1), 61-89. doi: 10.1016/10534822(91)90011-Z

Meyer, J. P., \& Allen, N. J. (1997). Commitment in the workplace: theory, research and application. Thousand Oaks, California: Sage.

Morris, J. H., \& Steers, R. M. (1980). Structural influences on organizational commitment. Journal of Vocational Behavior, 17(1), 50-57. doi: 10.1016/0001-8791(80)90014-7

Motta, P. C. (1999). Serviços: pesquisando a satisfação do consumidor. Rio de Janeiro: Papel Virtual.

Mowday, R. T., Steers, R. M., \& Porter, L. W. (1979). The measurement of organizational commitment. Journal of Vocational Behavior, 14(2), 224-247. doi: 10.1016/00018791(79)90072-1

Muthén, B. (1978). A general structural equation model with dichotomous variables. Psychometrika, 43(4), 551-560.

Naumann, S. T., Bennett, N., Bies, R. J., \& Martin, C. L. (1998). Laid off, but still loyal: the influence of perceived justice and organizational support. The International Journal of Conflict Management, 9(4), 356-368. doi: 10.1108/eb022815

Paz, M. G. T. (1999). Justiça no trabalho e poder organizacional. In M. G. T. Paz \& A. Tamayo (Orgs.), Escola, saúde e trabalho: estudos psicológicos (pp. 271-294). Brasília: Editora UnB.

Porter, L. W., Steers, R. M., \& Mowday, R. T. (2005). Do employee attitudes towards organizations matter? The study of employee commitment to organizations. In K. G. Smith \& M. A. Hitt (Eds.), Great minds in management: the process of theory development. Oxford, NY: Oxford University Press.

Rawls, J. (1971). A theory of justice. Cambridge, MA: Harvard University Press.

Rego, A. (2002). Comprometimento afetivo dos membros organizacionais: o papel das percepções de justiça. Revista de Administração Contemporânea, 6(2), 209-241. doi: 10.1590/S141565552002000200012

Rego, A., \& Sousa, L. (2000). Impactos dos comportamentos de cidadania docente sobre os alunos universitários - a perspectiva dos estudantes e professores. Linhas Críticas, 6(10), 9-30.

Roch, S. G., \& Shanock, L. R. (2006). Organizational justice in an exchange framework: clarifying organizational justice distinctions. Journal of Management, 32(2), 299-322. doi: $10.1177 / 0149206305280115$

Salancik, G. (1977). Commitment and control or organizational behavior and belief. In B. Staw \& G. Salancik (Eds.), New directions in organizational behavior (pp. 1-54). Chicago: St Clair Press.

Santos, A. R., \& Odelius, C. C. (2005, September). Percepção de justiça organizacional de sistemas de remuneração em organizações públicas. Proceedings of the Encontro Nacional da Associação Nacional de Pós-Graduação e Pesquisa em Administração, Brasília, DF, Brazil, 29.

Simons, T., \& Roberson, Q. (2003). Why managers should care about fairness: the effects of aggregate justice perceptions on organizational outcomes. Journal of Applied Psychology, 88(3), 432-443. doi: 10.1037/0021-9010.88.3.432 
Tanaka, J. (1987). "How big is big enough?": sample size and goodness of fit in structural equation models with latent variables. Child Development, 58(1), 134-146.

Thibaut, J., \& Walker, J. (1975). Procedural justice: a psychological analysis. Hillsdale, NJ: Erlbaum.

Tyler, T. R., \& Bies, R. J. (1990). Beyond formal procedures: the interpersonal context of procedural justice. In J. S. Carrol (Ed.), Applied social psychology in business settings (pp. 77-98). Hillsdale, NJ: Erlbaum. 